\title{
PENANAMAN PROSES PENDISPLINAN DIRI ANAK BERKEBUTUHAN KHUSUS (TUNA RUNGU WICARA) DALAM PEMBELAJARAN TARI TRADISIONAL
}

\author{
Maria Denok Bekti Agustiningrum ${ }^{1}$
}

\begin{abstract}
ABSTRAK
Anak-anak berkebutuhan khusus termasuk didalamnya anak tuna rungu-wicara adalah anak-anak yang juga mempunyai hak untuk mendapatkan pengajaran dan berkembang sesuai potensi yang mereka punyai. Menurut data dinas sosial saat ini jumlah anak yang mengalami tuna rungu wicara ada sejumlah 73.560 jiwa / 2013. Menjadi catatan bahwa masing-masing anak memiliki potensi yang besar untuk dapat berprestasi sehingga berdaya guna bagi masyarakat. Seperti halnya anak-anak normal pada umumnya maka anak tuna rungu-wicara memiliki beberapa masalah yang harus dicarikan solusinya agar mereka dapat berprestasi secara maksimal. Salah satu permasalahan yang dimiliki anak-anak berkebutuhan khusus khususnya tuna rungu-wicara adalah kurang percaya diri yang muncul melalui sikap moody dan menarik diri dari pergaulan. Solusi dari permasalahan tersebut dalam penelitian ini menemukan fakta bahwa pembelajaran tari tradisional mampu digunakan sebagai media menanamkan disiplin diri pada anak tuna rungu-wicara. Setiap langkah dari awal hingga akhir dalam pembelajaran tari tradisional yang mereka pelajari harus lewati secar bertahap dan berkesinambungan sehingga menjadi sebuah cara pendisiplinan diri yang tinggi.

Kata kunci: Tuna Rungu-wicara, Pembelajaran Tari, Pendisplinan diri.
\end{abstract}

\section{A. PENDAHULUAN}

Kemampuan untuk bertahan hidup dalam sebuah komunitas merupakan kebutuhan mendasar dari tiap manusia, terlepas bagaimana bentuk fisik individu. Individu terlahir memiliki potensi untuk mampu bertahan hidup, menurut beberapa ahli psikologi perkembangan (Atkinson, 1996: 21) seorang individu memiliki potensi terus berkembang selama hidupnya sampai akhir hayatnya. Kemampuan untuk terus berkembang dipengaruhi oleh kondisi lingkungan dimana individu hidup dan berkembang. Salah satu kemampuan yang harus dimiliki seorang individu untuk mampu menghadapi setiap permasalahan adalah disiplin diri (Utami Munandar, 2002). Disiplin diri pada umumnya memiliki pengertian sebuah kemampuan yang dimiliki individu untuk terus dapat dengan setia melakukan sesuatu sampai tercapainya sebuah tujuan. Bahkan disiplin diri menjadi sebuah latihan yang bertujuan mengembangkan diri agar memiliki karakter tertib.

Anak tuna rungu wicara adalah anak-anak yang memiliki berbagai macam permasalahan dikarenakan ketidak mampuannya dalam berkomunikasi dengan lingkungan dimana dia tumbuh dan berkembang. Ketidak mampuan dalam berkomunikasi tersebut menambah daftar permasalahan selain permasalahan umum yang terjadi pada tumbuh kembang anak normal. Ketidakmampuan bersosialisasi

${ }^{1}$ (Staff Pengajar PG-PAUD / FIP / IKIP Veteran Semarang) mariadenok@rocketmail.com 
dan diterima di masyarakat menjadi menjadi salah satu pemicu anak-anak tuna rugu-wicara mudah curiga dan putus asa. Masalah tersebut perlu dicarikan solusi mengingat keberadaan anak tuna rungu wicara menurut data dinas sosial di Indonesia pada tahun 2013 mencapai 73.560 jiwa, sedangkan masih banyak jumlah anak-anak berkebutuhan khusus yang lain yang memiliki ketunaan (daksa, netra, $\mathrm{dsb})$.

Melihat angka tersebut kita tidak dapat menutup mata bahwa sesungguhnya anak-anak yang memiliki ketunaan sesungguhnya memilki potensi besar untuk dapat berkembang dan berdaya guna bagi masyarakat. Beberapa dari anak-anak berkebutuhan khusus memiliki prestasi dibidang mereka yang bahkan mengharumkan nama bangsa Indonesia di kacah Internasional, kemampuan serta potensi yang mereka miliki mampu memberikan kontribusi terhadap keberadaan masyarakat dimana mereka berada.

\section{B. PEMBAHASAN}

Sama seperti keberadaan anak-anak normal pada umumnya maka anak-anak tuna rungu-wicara membutuhkan stimulasi agar kemampuan mereka dapat dioptimalkan. Beberapa sarana dan media diperlukan untuk menstimulasi potensi mereka dan menjawab setiap permasalahan yang dihadapi oleh anak-anak tuna rungu-wicara.pembentukan karakter yang baik merupakan modal utama dalam menstimulasi anak-anak tuna rungu-wicara agar dapat berprestasi mengingat banyaknya permasalahan yang muncul dikarenakan ketunaan yang mereka miliki. Maka langkah awal agar anak-anak tuna rungu wicara dapat menjadi bagian masyarakat yang berdaya guna melalui prestasi mereka adalah dengan mendisiplinkan anak tuna rungu wicara.

Disiplin diri diperlukan untuk menjawab salah satu permasalahan yang selalu dialami oleh anak tuna rungu-wicara yaitu moody yang berlebihan dan menarik diri atau bahkan menutup dari sebuah komunitas serta kurang percaya diri; Penyebab utamanya adalah komunikasi yang terputus. Maka peneliti mencoba menjawab permasalahan tersebut melalui media seni. Seni merupakan media ekspresi jiwa manusia, ekspresi yang dimiliki oleh tiap manusia sebagai ungkapan dari perasaannya. Setiap manusia mempunyai hak yang sama dalam mengungkapkan ekspresinya melalui seni namun setiap manusia memiliki kemampuan berkesenian yang berbeda-beda satu dengan yang lain.

Kemampuan berkesenian bisa diperoleh melalui sebuah proses pembelajaran ataupun diperoleh karena bakat / talenta. Seni sebagai sebuah media ekspresi jiwa manusia memiliki banyak cabang. Diantara cabang seni tersebut terdapat seni tari, seni tari adalah sebuah seni yang menekankan tubuh sebagai media ungkapan ekspresinya, walaupun didalam seni tari terdapat unsur-unsur lain selain gerak yang mengikat didalamnya. Seni tari memiliki berbagai unsur yang membentuknya, diantaranya adalah musik; Musik dalam seni tari memiliki fungsi yang bermacammacam, yaitu: mengiringi, pemberi suasana dan menjadi ilustrasi ( Jazuli, 2007: 14). Melihat dari fungsinya maka musik memiliki posisi yang penting disamping gerak itu sendiri. Namun Wisnoe Wardhana ( Dikti, 1990: 36 ) mengungkapkan bahwa pendidikan seni tari memiliki dua tujuan, yaitu: Secara langsung dan tidak secara 
langsung. (1) Secara langsung bertujuan untuk mengarahkan siswa agar dapat menari dengan baik sesuai dengan wirama, wirasa dan wiraga dan (2) Secara tidak langsung mempunyai tujuan untuk menanamkan nilai-nilai yang terkandung dalam seni tari atau dengan kata lain membentuk kepribadian dari sipembelajar.

Nilai-nilai yang terkandung dalam seni tari masih menurut Wisnoe Wardhana adalah: disiplin diri yang ketat, kerapian sikap dan gerak, kecepatan adaptasi, keberanian bertindak, tanggung jawab yang besar, kedalaman penghayatan, keasyikan hobby, dedikasi dan keuletan. Menunjuk dari penjelasan tentang fungsi tari dari beberapa pernyataan diatas maka dapat ditarik kesimpulan bahwa memiliki kesempurnaan fisik bukan menjadi kendala bagi seorang individu karena hakekat dari seni adalah media ekspresi maka demikian pula seni tari sebagai suatu media ekspresi manusia yang pengungkapannya melalui gerak sehingga mampu membuat si pembelajar merasakan nilai-nilai yang terkandung dalam seni tari. Keterbatasan fisik tidaklah menjadi hal yang prinsip apabila sipembelajar tersebut mampu mengungkapkan ekspresinya dan mampu merasakan nilai-nilai yang terkandung dalam seni tari yaitu: disiplin diri yang ketat, kerapian sikap dan gerak, kecepatan adaptasi, keberanian bertindak, tanggung jawab yang besar, kedalaman penghayatan, keasyikan hobby, dedikasi dan keuletan.

Tuna rungu adalah kondisi fisik yang dialami oleh seseorang yang tidak memilki kemampuan untuk mendengarkan suara dalam bentuk apapun, biasanya seorang tuna rungu juga menderita tuna wicara atau ketidak mampuan untuk berbicara. Ada beberapa kategori anak berkebutuhan khusus lainnya namun dalam penelitian ini peneliti hanya membatasi pada keberadaan anak - anak tuna runguwicara.

Dalam beberapa hal kehilangan pendengaran dapat mengakibatkan ketidakmampuan belajar yang lebih serius dibanding kehilangan penglihatan (anak tuna netra). Kemahiran dan kemampuan menggunakan bahasa simbol biasanya lebih sulit bagi anak dengan ngangguan pendengaran, hal tersebut dapat dilihat dari tumbuh kembang sejak masa bayi; Seorang anak tuna rungu-wicara memiliki kesulitan belajar untuk mengenali suara, terutama suara ibunya sehingga respon yang dimilikinya lamban dibandingkan dengan anak tuna netra. Ketidakmampuan belajar ini yang menjadi salah satu faktor anak-anak tuna rungu-wicara memiliki tingkat kecerdasan dibawah rata-rata anak pada umumnya. Ketidakmampuan belajar pada anak tuna rungu-wicara mempengaruhi psikologis anak tuna runguwicara.

Beberapa penelitian ahli menyebutkan bahwa anak-anak tuna rungu-wicara mengalami kesulitan belajar / learning disabilities, keterbelakangan mental / mental retardision, dan gangguan emosi / emotional disabilities ( John David, 2009: 267 ). Kesulitan belajar yang dialami oleh anak tuna rungu-wicara adalah kesulitan belajar dalam semua segi kehidupan, hal tersebut dikarenakan tidak adanya gambaran jelas tentang apa yang mereka pelajari. Kesulitan belajar disebabkan oleh beberapa faktor diantaranya adalah besarnya rasa rendah diri anak tuna rungu-wicara atau kurang adanya rasa Percaya Diri terhadap anak-anak tuna rungu-wicara. Kesulitan belajar menjadi hal yang sangat penting untuk ditangani atau diberikan jawaban agar anakanak tuna rungu-wicara dapat terus eksis dalam masyarakat umum. 
Seorang dikatakan tuna rungu-wicara apabila mereka kehilangan daya dengarnya sedemikian rupa sehingga untuk pengembangan potensinya diperlukan pendidikan khusus. Menurut David ( 2009: 274 ) Klasifikasi berkurangnya pendengaran menurut lokasi anatomis meliputi: (a) Conductive Hearing Loss, adalah kondisi berkurangnya kemampuan mendengar dikarenakan rusaknya organ fisik dari telinga: (b) Sensorineural Hearing Loss, adalah kondisi berkurangnya kemampuan mendengar dikarenakan rusaknya syaraf organ telinga; (c) Mixed Hearing Loss, adalah kondisi berkurangnya kemampuan mendengar dikarenakan rusaknya organ fisik dari telinga dan rusaknya syaraf organ telinga. Tuna rungu-wicara adalah individu yang memiliki hambatan dalam pendengaran baik permanen maupun tidak permanen. Klasifikasi tuna rungu-wicara berdasarkan tingkat gangguan pendengaran adalah: (1) Gangguan pendengaran sangat ringan(27-40dB), (2) Gangguan pendengaran ringan (41-55dB), (3) Gangguan pendengaran sedang (56-70dB), (4) Gangguan pendengaran berat (71-90dB), (5) Gangguan pendengaran ekstrem/tuli (di atas 91dB).

Karena memiliki hambatan dalam pendengaran individu tuna rungu memiliki hambatan dalam berbicara sehingga mereka biasa disebut tuna wicara. Cara berkomunikasi dengan individu menggunakan bahasa isyarat, untuk abjad jari telah dipatenkan secara internasional sedangkan untuk isyarat bahasa berbeda-beda di setiap negara. Saat ini dibeberapa sekolah sedang dikembangkan komunikasi total yaitu cara berkomunikasi dengan melibatkan bahasa verbal, bahasa isyarat dan bahasa tubuh. Individu tuna rungu-wicara cenderung kesulitan dalam memahami konsep dari sesuatu yang abstrak. Dinegara Indonesia ada simbol bahasa isyarat yang dipatenkan atau dipergunakan SIBI (Simbol Isyarat Bahasa Indonesia). SIBI ini dipergunakan dalam komunikasi baik disekolah maupun ditempat umum lainnya.

Terdapat 2 faktor utama penyebab gangguan pendengaran, yaitu: faktor genetik dan faktor lingkungan.1) Faktor Genetik ( Northernand, 1974: 243 ) Faktor Genetik adalah faktor yang muncul pada saat proses pembentukan janin. Penyebab gangguan pendengaran yang ditularkan oleh orangtua kepada anak-anaknya, melalui gen-gen resesif yang berarti orangtua mempunyai pendengaran normal maupun gen - gen domain yang berarti orang tua baik salah satu maupun keduanya mempunyai dasar gangguan pendengaran. 2) Faktor Lingkungan Pengalaman Faktor Lingkungan / Pengalaman adalah faktor yang muncul pada saat anak sudah lahir. Faktor lingkungan dibedakan menurut penyebab peristiwa, yaitu: (a) Lahir Prematur / Premature Birth, (b) Campak / Viral Infection, tertularnya bayi oleh virus maternal rubella, (c) Tertular virus radang selaput otak / encephalitis, sumsum tulang belakang, meningitis, penyakit gondok / mumps, (d) Ketidaksesuaian Rh darah, (e) Radang telinga tengah, (f) Pemakaian obat - obat tertentu dan beberapa faktor kebiasaan hidup yang buruk (David J., 2009: 279 ).

Dikarenakan alat pendengarannya tidak mampu berfungsi dengan baik maka permasalahan anak tuna rungu-wicara adalah pada komunikasi. Ciri umum yang lain adalah kemampuan intelektual mereka berada dibawah rata-rata anak pada umumnya dan memiliki gangguan pada kemampuan sosial-emosi yang kurang stabil.Anak tuna rungu-wicara pada umumnya memiliki tingkat kecerdasan yang cenderung sama dengan anak-anak normal lainnya, tetapi dikarenakan terputusnya 
informasi yang diterima oleh otak maka Anak Tuna rungu-wicar nampak seperti anak dengan tingkat kecerdasan dibawah rata-rata atau dalam istilah medis disebut dengan "Bodoh Semu” ( Sastrawirata, 1977: 54 ). Anak-anak tuna rungu adalah anakanak yang cenderung memiliki kecurigaaan yang besar terhadap lingkungan disekitarnya, hal tersebut dikarenakan mereka tidak bisa mendengar suara apapun yang ada disekitarnya. Kecurigaan tersebut menyebabkan mereka untuk menarik diri dan cenderung menjadi eksklusif.

Beberapa permasalahan yang berada diseputar anak-anak tuna rungu wicara tersebut yang semakin memberikan dampak buruk bagi pembentukan karakternya. Karakter yang bagus diperlukan dalam berbagai bidang pekerjaan; Seorang anak tuna rungu-wicara menjadi bagian dalam sebuah komunitas masyarakat pekerja, dibanyak sektor pekerjaan kita dapat menjumpai mereka menjadi bagian dari komunitas ( penjahit, petani, peternak, koki,dsb ). Penelitian ini mencoba mencarikan solusi bagi banyaknya permasalahan yang dihadapi oleh anak-anak tuna rungu, terkhusus masalah penanaman proses pendisiplinan diri. Doni Koesoema (2007) dalam bukunya Pendidikan Karakter menyebutkan bahwa penanaman karakter terbentuk dari lingkungan dimana individu berada; maka dapat ditarik kesimpulan untuk dapat memperoleh karakter yang bagus harus ditanamkan sejak dini. Karakter yang baik dibutuhkan dalam setiap aspek kehidupan, dimaksudkan disini bahwa penanaman karakter menjadi hal mutlak dalam setiap ranah kehidupan terlepas dari keberadaan fisik individu tersebut.

Penelitian ini mempunyai tujuan untuk menjawab permasalahan tentang pentingnya sebuah pendisiplinan bagi anak tuna rungu wicara melalui pembelajaran tari tradisi. Penelitian ini dilakukan dibeberapa sekolah SLB yang mewakili SLB-C di jawa tengah. A. Proses Pembelajaran Tari Bagi Siswa Tuna Rungu-Wicara Menurut Departemen Pendidikan Nasional Derektoran Menejemen Pendidikan Dasar dan Menengah Direktorat Sekolah Luar Biasa ( 2006: 1-5 ) Kurikulum yang diterapkan di SLB pada dasarnya sama seperti yang diterapkan pada sekolah umum yang ada di Indonesia, mengalami beberapa perubahan sesuai dengan kebijakan dari pemerintah. Adapun beberapa kurikulum yang pernah dilaksanakan di SLB adalah kurikulum tahun 1994, kurikulum KBK tahun 2004, kurikulum KTSP 2006.Disebutkan dalam standar isi, standar kompetensi lulusan dan panduan penyusunan KTSP untuk jenjang SLB-B maka pembelajaran seni tari masuk dalam program khusus BKPBI dari tingkat SDLB, SMPLB sampai dengan SMALB. Materi pelajaran mata pelajaran tari disesuaikan dengan tingkat kemampuan siswa. Dikarenakan merupakan mata pelajaran BKPBI maka tidak ada keterikatan dan standart penilaian yang baku yang dibuat oleh Dinas Pendidikan. Standar penilaian hanya dari kemampuan siswa mampu melakukan dengan baik.

Dari kurikulum yang muncul tersebut maka memberi ruang gerak kepada setiap sekolah untuk membebaskan penggunaan seni tari dalam pembelajarannya. Tidak ada ketentuan yang mengingat sekolah untuk mempergunakan tari sebagai sebuah mata pelajaran wajib. Walau demikian berdasarkan hasil penelitianini ditemukan $85 \%$ sekolah mempergunakan seni tari sebagai sebuah mata pelajaran yang diajarkan disekolah. Adapun pembelajaran tari yang dilakukan disekolah adalah sebagai berikut: A.1. Penyampaian materi dengan mempergunakan bahasa 
simbol sehari-hari bagi anak tuna rungu-wicara. Percakapan yang biasa dilakukan dalam pembelajaran sehari-hari bagi siswa-siswi tuna rungu-wicara adalah percakapan bahasa Indonesia dengan sistem isyarat yang dikeluarkan oleh Direktorat Jendral Pendidikan Dasar dan Menengah Direktur Pendidikan Luar Biasa. Bahasa tersebut dinamakan Sistem Isyarat Bahasa Indonesia (SIBI), berwujud tatanan yang sistematis tentang seperangkat isyarat jari, tangan dan berbagai gerak yang melambangkan kosa kata Bahasa Indonesia. SIBI dilakukan dalam pembelajaran seni tari khususnya sebagai pengantar materi dan instruksi-instruksi yang diinginkan oleh guru pengajar. Contoh apabila guru mengucapkan salam, menanyakan kondisi siswa-siswi, menyuruh mengulang materi dan beberapa hal lain yang terkait materi pembelajaran. A. 2. Penyampaian materi dengan mempergunakan bahasa isyarat tangan untuk menyimbolkan gerak dasar tari. Pengenalan gerak dasar tari adalah tahapan pembelajaran yang dilakukan diawal pelajaran yang berfungsi untuk mengenalkan gerak-gerak dasar yang dilakukan dalam pembelajaran seni tari bagi siswa tuna rungu-wicara .Pengenalan Gerak tersebut meliputi: (1) Gerak-gerak dasar/posisi tubuh,tangan,kaki,kepala. (2) Gerak-gerak dasar dalam bentuk sekaran. Pengenalan gerak ini tidak semua gerakan simbolkan oleh guru namun simbol diberikan hanya untuk gerakan yang umum atau sering dilakukan dalam semua tari yang diajarkan.

Dalam seni tari terdapat beberapa simbol kosakata yang melambangkan gerak tertentu yang penggunaan istilah tersebut hanya digunakan dalam bahasa tari. Contoh dari simbol kosakata tersebut adalah kengser, trisig, panggel, mendhak. Untuk memudahkan penyampaian materi maka guru pengajar membuat beberapa isyarat/aba-aba baku yang bertujuan untuk mempermudah penyampaian materi. Simbol yang dipergunakan mirip dengan SIBI yang intinya mempergunakan jari dan tangan untuk mengganti bahasa verbal atau menyimbolkan pernyataan tertentu. A.3. Penyampaian Pola Lantai dengan simbol. Pembelajaran seni tari merupakan pembelajaran yang utuh, utuh memilki arti pembelajaran dilakukan mulai dari proses pengajaran hingga pementasan. Untuk menuju ke pementasan maka ada tahapan yang harus dimengerti siswa. Setelah siswa mengerti gerakan-gerakan dan urutannya dalam sebuah gerak maka siswa mendapatkan pembelajaran mengenai pola lantai.

Menurut Wisnoe Wardhana, yang dimaksud dengan pola lantai adalah garis yang dilalui penari diatas pentas. Maka sebuah tari memiliki pola lantai yang memperindah tari tersebut.Penyampaian pola lantai bagi siswa normal yang mempelajari tari bukan sesuatu yang sulit, dikarenakan guru pada umumnya menginstruksikannya dengan suara sehingga siswa paham harus berubah pola lantai. Tetapi hal tersebut menjadi tidak efektif bila diberikan kepada siswa tuna rungu-wicara dikarenakan ketidakmampuan mereka menangkap bunyi/mendengar. Untuk mengatasi hal tersebut maka sebagai seorang guru tari bagi siswa tuna runguwicara maka penyampaian pola lantai tari kepada siswa tuna rungu-wicara dengan cara membuat simbol-simbol tertentu yang menolong siswa memahami perintahnya A.4. Penyampaian materi melalui metode Imitasi. Metode Imitasi adalah metode yang umum dilakukan dalam pembelajaran tari yaitu dengan cara guru memberi contoh gerakannya dan siswa menirukan gerakan yang dicontohkan 
guru.Penggunaan metode Imitasi dalam pembelajran tari untuk anak tuna runguwicara digunakan dalam metode pengenalan gerak dasar. Seperti gerak Lampah telu, Lambeyan miwir Sampur, Sembahan, dsb. A. 5. Repetisi / pengulangan gerak. Langkah berikutnya pada pembelajaran tari bagi siswa tuna rungu-wicara adalah repetisi / pengulangan gerak. Langkah ini umum dilaksanakan pada siswa yang normal maupun siswa tuna rungu wicara.

\section{PENUTUP}

Memahami beberapa proses yang harus dilakukan oleh anak tuna runguwicara dalam mempelajari tari maka dibutuhkan sikap pendisiplinan diri yang tinggi agar anak tuna rungu-wicara dapat melakukan sebuah tarian dengan baik dan benar. Proses penanaman disiplin dalam pembelajaran tari nampak pada setiap tahapan yang harus dilalui satu persatu tanpa membolak-balik serta kemampuannya dalam berkonsentrasi dalam setiap tahapan.

Kemampuan berkonsentrasi dan menghafal dengan urutan benar kemudian menampilkannya sejak awal sampai akhir sebuah tarian menjadi bukti seorang anak tuna rungu wicara mampu menunjukkan sikap disiplin diri yang tinggi. Hal tersebut menjadi sebuah tolok ukur dikarenakan salah satu kesulitan dari anak tuna rungu wicara karena anak tuna rungu -wicara memiliki salah satu permasalahan pendisiplinan diri rendah ditunjukan dengan sulit mengikuti perintah, sulit diatur dan cenderung bersikap semaunya sendiri. Beberapa sikap disiplin diri yang rendah tersebut disebabkan ketidak mampuan anak tuna runguwicara untuk berkomunikasi benar dengan orang-orang disekelilingnya. Pembelajaran tari tradisonal menjadi sebuah media yang dianggap mampu untuk mengakomodir sikap kurang disiplin pada anak tuna rungu-wicara, tahapantahapan yang harus dilakuakan untuk dapat menguasai sebuah tari tradisional menjadi sebuah latihan yang efektif agar anak tuna rungu-wicara mampu mendisiplinkan dirinya.

\section{DAFTAR PUSTAKA}

Abin Syamsuddin Makmun. 2003. Psikologi Pendidikan. Bandung: Rosda Karya Remaja

Alison Clacke and Stewart Susan F. 1987. Child Development infancy through Adolescense. Boston: John Wiley and Sons Inc

Alwisol. 2009. Psikologi Kepribadian ( Edisi Revisi ). Malang: UMM Press

Ardhana, W. 2000. Reformasi pembelajaran menghadapi abad pengetahuan. Makalah. Disajikan dalam Seminar dan Diskusi Panel Nasional Teknologi Pembelajaran V, tanggal 7 Oktober 2000, di UM.

Arends, R. I. 1998. Learning to teach. Singapore: Mc Graw-Hill book Company.

Arends, R. I., Wenitzky, N. E., \& Tannenboum, M. D. 2001. Exploring teaching: An introduction to education. New York: McGraw-Hill Companies.

Atkinson, Rita. Richard. Ernest. 1996. Pengantar Psikologi. Jakarta: Erlangga.

Bloom, Benjamin S.1982. Human characteristics and school learning. New York :

McGraw-Hill BookCompany. 
Brook, B.D., \& Goble. 1997. The Case for Character Education; The Role of the School in Teaching Values and Virtue. Northridge,CA.: Studio 4 Productions.

Cervone Daniel; Pervin L. 2011. Kepribadian ( Teori dan Penelitian ). Jakarta: Salemba Humanika.

David Smith J. 2009. Inklusi ( Sekolah Ramah Untuk Semua ). Bandung: Nuansa

Dedi Supriawan dan A. Benyamin Surasega, 1990. Strategi Belajar Mengajar (Diktat Kuliah). Bandung: FPTK-IKIP Bandung. Departemen Pendidikan Nasional. 2006. Standart Isi, Standart Kompetensi Lulusan dan Panduan Penyusunan KTSP Tunarungu "B". Jakarta: Direktoran Manajemen Pendidikan Dasar dan Menengah Direktorat Pembinaan Sekolah Luar Biasa.

Dewantara, Ki Hadjar. 1977. Karya Ki Hadjar Dewantara : Bagian Pertama Pendidikan. Yogyakarta: Majelis Luhur Persatuan Taman Siswa.

Erickson Marilyn. 1980. Child Development and Developmental Disabilities. Boston: Little Brown and Company.

Ellah Siti Chalidah. 2005. Terapi Permainan Bagi Anak Yang Memerlukan Layanan Pendidikan Khusus. Jakarta: DIKTI

Fajrie Nur. 2011. Pengembangan Perangkat Pembelajaran Seni Rupa Dengan Bahan Tanah Liat Untuk Siswa SDLB-A Negeri Di Semarang. Tesis. Program Studi Pendidikan Seni Program Pasca Sarjana UNNES.

Fatchul Mu'in, 2011. Pendidikan Karakter ( Konstruksi Teoritik dan Praktik ). Yogyakarta: Ar-Ruzz Media.

Griffin, P., \& Nix, P. 1991. Educational assessment and reporting: A new approach.Sydney: Harcourt Brace Jovanovich, Publishers.

Gulo, W. 2002. Strategi Belajar - Mengajar. Jakara: Grasindo.

Gunter, M. A., Estes, T. H., \& Schwab, J. H. 1990. Instruction: A models approach. Boston: Allyn and Bacon.

Gagne, Robert M. dan Driscoll, Marcy P. 1988. Essentials of learning for instruction. Englewood Cliffs, NJ.: Prentice-Hall, Inc.

Hellen Keller. 2010. The Story Of My Life. Jakarta Selatan: Genta Pustaka.

Hurlock, B. Elisabeth 2000. Perkembangan Anak (jilid 1). Jakarta: Erlangga.

Indriani Yessi. 2010. Tutorial Teman Sebaya Untuk Meningkatkan Ketrampilan Sosial Anak Autis. Tesis: Program Studi Magister Profesi Pasca Sarjana UNIKA.

Jazuli. M. 2008. Pendidikan Seni Budaya ( Suplemen Pembelajaran seni Tari). Semarang: Unnes Press.

John W. Creswell. 2010. Research Design ( Pendekatan Kualitatif, Kuantitatif dan Mixed ). Yogyakarta: Pustaka Pelajar.

Jonet Sri Kuncoro. 2009. Karya Tari Sebuah Catatan Harian. Jurnal Greget Surakarta: Vol VIII/ No 1/ 2009

Khan, Yahya. 2010. Pendidikan Karakter Berbasis Potensi Diri. Yogyakarta: Pelangi Publishing.

Keller, John M. 1983. Motivational design instruction dalam Charles M Reigeluth (ed.), Instructional design theories and models, 383-430. Hillsdale, NJ.: Lawrence Erlbaum Associates, Publishers.

Keller, John M. 1987. Development And Use Of ARCS Model Of Instructional Design, Journal of Instructional Development, Vol. 10 (3), 2-9. 
Keller, John M. dan Thomas W. Kopp. 1987. An application of the ARCS model of motivational design, dalam Charles M. Reigeluth (ed), Instructional theories in action, 289-319. Hillsdale, NJ: Lawrence Erlbaum Associates, Publishers.

Koesoema Doni. 2007. Pendidikan Karakter. Jakarta: Kompas Gramedia

Kodiran. 2004. Pewarisan Budaya Dan Kepribadian Jurnal Humaniora . Semarang: Vol XVI/ No 1 / 2004.

Kuhn, T. S. 2002. The structure of scientific revolution. Diterjemahkan oleh: Tjun

Moleong, Lexy. 2004. Metodologi Penelitian Kualitatif. Bandung: Remaja Rosdakarya Offset

Munandar, Utami. 1999. Pengembangan Kreativitas Anak Berbakat. Jakarta

Pusat Perbukuan DIKBUD dan PT. Reksa Cipta.

Nasution, S. 1989. Kurikulum Dan Pengajaran. Bandung: Bumi Aksara.

Northern J. 1974. Hearing In Children. Baltimore: MD Williams and Wilkins

Rahma, Y. Kurniati, L. 2010. Strategi Pengembangan Kreativitas Pada Anak. Jakarta: Kencana Prenada Media Group.

Reigeluth, C. M. (Ed.). Instructional-design theories and models: A new paradigm of instructional theory, volume II. 5-29. New Jersey: Lawrence Erlbaum Associates, Publisher.

Santyasa, I W. 2003. Pendidikan, pembelajaran, dan penilaian berbasis kompetensi. Makalah. Disajikan dalam seminar Jurusan Pendidikan Fisika IKIP Negeri Singaraja, 27 Februari 2003, di Singaraja.

Santyasa, I W. 2003. Pembelajaran fisika berbasis keterampilan berpikir sebagai alternatif implementasi KBK. Makalah. Disajikan dalam Seminar Nasional Teknologi Pembelajaran, 22-23 Agustus 2003, Di Hotel Inna Garuda Yogyakarta.

Sardjono. 2005. Terapi Wicara. Jakarta: Departemen Pendidikan Nasinal-Direktorat Jenderal Pendidikan Tinggi-Direktorat Pembinaan Pendidikan Tenaga Kependidikan Dan Ketenagaan Perguruan Tinggi.

Simon, H. A. 1996. The science of the artificial. Third edition. London: The MIT Press. Slavin, R. E. 1995. Cooperative learning. Second edition. Boston: Allyn and Bacon.

Syahnur Rahman. 2011. Faktor-faktor yang mempengaruhi konsep diri dan peneysuaian diri pada remaja. Jurnal Pedagogia. Bandung: Volume 9 / No 2 /158-167.

Tim Peningkatan Kualitas Pendidikan Tinggi Seni di Indonesia. 2007. Paradigma Baru Pendidikan Tinggi Seni Indonesia. Jakarta: DIKTI.

Tri Elisabeth, A.P. 2010. Efektifitas Terapi Musik untuk meningkatkan kemampuan Kontak Mata pada Anak autis. Tesis: Program Studi Magister Profesi Pasca Sarjana UNIKA;

Totok Sumaryanto. F. 2007. Pendekatan Kuantitatif Dan Kualitatif ( Dalam Penelitian Pendidikan Seni ). Semarang: Unnes Press.

Udin S. Winataputra. 2003. Strategi Belajar Mengajar. Jakarta: Pusat Penerbitan Universitas Terbuka.

Wardhana Wisnoe. 1990. Pendidikan Seni Tari Buku Guru Menengah Sekolah Pertama. Jakarta: Depdikbud.

Wina Senjaya. 2008. Strategi Pembelajaran; Berorientasi Standar Proses Pendidikan. Jakarta: Kencana Prenada Media Group. 